AGRICULTURE AND BIOLOGY JOURNAL OF NORTH AMERICA

ISSN Print: 2151-7517, ISSN Online: 2151-7525, doi:10.5251/abjna.2011.2.6.1032.1037

(C) 2011, ScienceHu $\beta$, http://www.scihub.org/ABJNA

\title{
The abundance and distribution of plankton species in the bonny estuary; Nigeria
}

\author{
Ajuonu $\mathrm{N}^{1^{*}}$, Ukaonu S.U ${ }^{1}$ Oluwajoba E.O ${ }^{1}$, Mbawuike B.E, Williams A B ${ }^{1}$, Myade E.F ${ }^{1}$, \\ ${ }^{1}$. Marine Biology Section, Nigerian Institute for Oceanography and Marine Research, Victoria \\ Island, Lagos Nigeria. 1*08055847954. Email: n.ajuonu@yahoo.com
}

\begin{abstract}
The plankton community in the bonny estuary was studied. A total population of 2846 plankton was indentified comprising of 2172 Phyto plankton and 674 of Zooplankton measured in cells per litre $X 10^{6}$. This population comprised of 63 species made up of 32 Phyto and 31 Zoo. Cosnodiscus radiatus (Diatom) was the highest in abundance and distribution constituting $48.4 \%$ (1052 in number) of the entire phytoplankton community and occurring in all the 7 stations studied. This was followed by cosnodiscus lineatus and Biddulphia sinenses (all Diatom) with $9.5 \%$ and $9.02 \%$ in abundance. For the zooplankton, the Pseudocallanus elongatus ( A copepod) was the highest in both occurrence and abundance constituting 45.5\% ( 307 in number) of the entire zooplankton and occurring in all the 7 stations. The Cladocera represented by Pondo lueceti and Evadne nordmani $9.3 \%$ and $7.2 \%$ respectively followed in abundance.
\end{abstract}

Keywords: Plankton, Estuary, Community, Abundance and Distribution.

\section{INTRODUCTION}

The Phytolankon constitute the most important component of the food chain in every water body. All other living organisms in water depend directly or indirectly on them for food. A knowledge of the plankton community of any water body is therefore, not only important in assessing its productivity but would permit a better understanding of the population dynamics and life cycles of the fish community ( Holden and Green, 1960, Williams 1962, Olaniyan 1969, Fagade and Olaniyan 1974, Adebisi 1981, Egborge 1981, Nwankwo 1986, Abohweyere1990 and Ugwumba 1990).

Estuarine plankton communities can respond to both climatic change and human activities at different time scale. There are obvious relationships between changes in plankton communities and water environmental factors. Hence, plankton may serve as a bioindicator to monitor estuarine environment for both pollution or as a modeling for fish population dynamics ( Nwankwo 2004, Onyema 2007).

The Bonny estuary play a very important role in the economy and food supply of the Bonny Kingdom serving as their major source of Fish and employment and even the nation at large being the channel through which the Nigerian Liquefied Natural Gas Company (LNG) batches enter the sea. In spite of these important roles the Bonny estuary play to the country at large, there is a dearth of information about the Plankton community of the water. A proper understanding of the abundance and species distribution of the plankton community of this water body will not only help in understanding the dynamics of its rich fishery resources but will also serve as a tool for predicting the impact of human activities in the water for future sustainable management. This work is therefore, a preliminary incursion into the understanding of the abundance and distribution of the plankton community of the water. It will serve as a reference for future studies.

\section{MATERIALS AND METHODS}

Sample collection and analyses: The sampling area was divided into transects for easy sample collections. The plankton samples were collected between November 2004 and December 2005 covering two wet and two dry seasons. The depth area ranged between 6 to $25 \mathrm{~m}$. A duplicate sample were taken at each station by towing a plankton net of 53 microns at a low speed of about $2 \mathrm{kts}$ for Five (5) minutes onboard a vessel RV GEO Explorer. The sampling was done during the day i.e between daylight hours. The samples once collected were put in a sample bottle and stored with $5 \%$ formalin for Laboratory analyses.

In the laboratory, one $\mathrm{ml}$ of the preserved sample was taken as a sub sample using a pipette. The collected sample was put on the Sedgwick-rafter counting chamber and viewed under a light binocular 
microscope (Nikon 400 binocular microscope) using a low magnification of $\times 10$. A duplicate specimen was collected and analyzed for comparison and double checking. The observed planktons were identified to species level using relevant literature references

Ecological diversity indices: Species Richness Index (d): The Species richness index (d) according to Margalef (1951) was used to evaluate the community structure. The equation below was applied and results were recorded to two decimal places.

$d=(S-1) /$ Loge $N$

Where:

$\mathrm{d}=$ Species richness index

$S=$ Number of species in a population

$\mathrm{N}=$ Total number of individuals in $\mathrm{S}$ species.

Shannon and Weiner diversity index $(H)$ : Shannon and Weiner (1949) diversity index $(H)$ given by the equation:
$\mathrm{Hs}=-\Sigma \mathrm{Pi} 1 \mathrm{n} \mathrm{Pi}$

Where

$\mathrm{Hs}=$ Diversity Index

$\mathrm{i}=$ Counts denoting the ith species ranging from $1-\mathrm{n}$

$P I=$ Proportion that the ith species represents in terms of numbers of individuals with respect to the total number of individuals in the sampling space as whole.

\section{RESULTS:}

Table 1 presented the results of analyses of the ecological indices obtained using both the ShannonWeiner index $(\mathrm{H})$ for species diversity and Margalef index (D) for species richness. The results showed that $H$ values ranged from 0.87 in stations 1 and 2 to 1.61 in station 5 for Zooplankton and 0.88 in station 2 to 2.07 in station 7 for Phytoplankton. The $D$ values were 0.86 in station 2 to 2.48 in station 3 for Zooplankton and 1.44 in station 1 to 2.77 in station 7 for Phytoplankton.

Table 1. General caption: Abundance and distribution of species according to stations;

\begin{tabular}{|l|l|l|l|l|}
\hline \multirow{2}{*}{ STATION } & $\begin{array}{l}\text { H VALUE } \\
\text { SHANNON - } \\
\text { WEINER }\end{array}$ & PHYTO & \multicolumn{2}{l|}{ MARGALEF } \\
\cline { 2 - 5 } & ZOO VALUE & \multicolumn{2}{l|}{} \\
\hline 1 & 0.87 & 1.04 & ZOO & 1.44 \\
\hline 2 & 0.87 & 0.88 & 1.12 & 1.45 \\
\hline 3 & 1.24 & 1.79 & 0.86 & 2.12 \\
\hline 4 & 1.23 & 1.91 & 2.48 & 2.67 \\
\hline 5 & 1.61 & 1.53 & 1.56 & 1.99 \\
\hline 6 & 1.55 & 1.10 & 1.59 & 2.34 \\
\hline 7 & 1.25 & 2.07 & 2.33 & 2.77 \\
\hline
\end{tabular}

Biological diversity analyses 
Table 2: Zooplankton distribution

\begin{tabular}{|c|c|c|c|c|c|c|c|c|c|}
\hline \multirow{3}{*}{ ZOOPLANKTON } & & & & & & & & \multirow{3}{*}{$\begin{array}{l}\text { TOAL NO } \\
\text { IND IN ALL } \\
\text { STATIONS }\end{array}$} & \multirow{3}{*}{ TOTAL } \\
\hline & \multicolumn{6}{|c|}{$\begin{array}{l}\text { STATIONS AND NUMBER OF OCCURRENCE I } \\
\text { STATION }\end{array}$} & & & \\
\hline & 1 & 2 & 3 & 4 & 5 & 6 & 7 & & \\
\hline Pondon lueceti & 4 & 1 & 3 & 47 & - & - & 8 & 63 & 63 \\
\hline pseudocallanus elongatus & 1 & 77 & 121 & 27 & 4 & 6 & 71 & 307 & 307 \\
\hline Macrocallanus elongatus & 1 & - & - & - & - & - & - & 1 & 1 \\
\hline Parathemisto compressa & - & 4 & - & - & - & - & - & 4 & 4 \\
\hline Zoae (Crab) & & 6 & & 3 & & 30 & & 39 & 39 \\
\hline Microcallanus pusillus & - & 19 & 1 & - & - & - & 14 & 34 & 34 \\
\hline Arthropod larva & - & - & 3 & - & - & - & - & 3 & 3 \\
\hline Doloidid larva & - & - & 2 & - & - & - & - & 2 & 2 \\
\hline Eucallanus elongatus & - & - & 1 & - & - & - & - & 1 & 1 \\
\hline Evadne nordmani & - & - & 10 & 4 & 26 & 4 & 5 & 49 & 49 \\
\hline Evadne spinifera & - & - & 2 & 2 & 9 & - & - & 13 & 13 \\
\hline Temora longicornis & & & 2 & & & & & 2 & 2 \\
\hline Isias clavipes & & & 35 & & & & & 35 & 35 \\
\hline Metridian lucens & & & 1 & & & & & 1 & 1 \\
\hline Bisponusa & & & 1 & & & & & 1 & 1 \\
\hline Rhinocallanus nasutus & & & 1 & & & 1 & & 2 & $\underline{2}$ \\
\hline Eutherpina & & & 3 & & & & & 3 & 3 \\
\hline Splonid late larva & & & & 1 & & & & 1 & 1 \\
\hline $\begin{array}{l}\text { Parathemisto compressa va } \\
\text { compressa }\end{array}$ & & & & 2 & & & & 2 & 2 \\
\hline Anomalocera patasoni & & & & 1 & & & & 1 & 1 \\
\hline Eucampia zoodianus & & & & & 1 & & & 1 & 1 \\
\hline Polycheate larva & & & & & 1 & 1 & & 2 & 2 \\
\hline Fish larva & & & & & 26 & & & 26 & 26 \\
\hline Pondon intermidus & & & & & 12 & 24 & 1 & 37 & 37 \\
\hline Pondon lueceti lueceti & & & & & 2 & & & 2 & 2 \\
\hline Sagitella & & & & & & 1 & & 1 & 1 \\
\hline Brachyllura larva & & & & & & 1 & & 1 & 1 \\
\hline Phialela quadrata & & & & & & 2 & & 2 & 2 \\
\hline Rhizosolanea spp & & & & & & 1 & & 1 & 1 \\
\hline Centropages typicus & & & & & & 1 & & 1 & 1 \\
\hline Eucalanus nauptilus & & & & & & & 36 & 36 & 36 \\
\hline TOTAL NO IN ALL STATIONS & & & & & & & & 674 & 674 \\
\hline TOTAL NO IND / STATION & 6 & 107 & 186 & 87 & 81 & 72 & 135 & & \\
\hline
\end{tabular}


Table 3: Phytoplankton distribution and not Zooplankton distribution

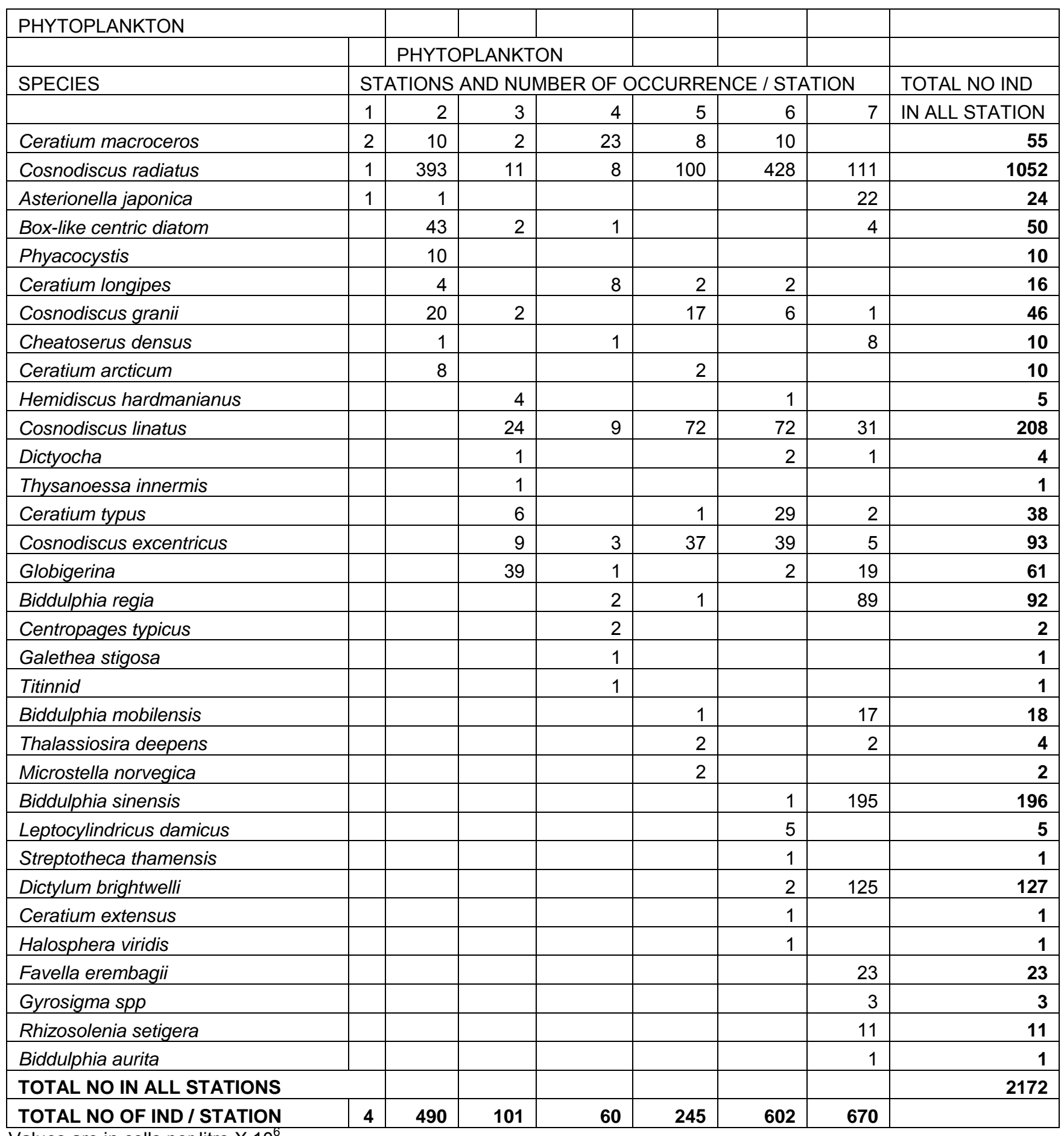

Values are in cells per litre $\times 10^{6}$ 


\section{PHYTOPLANKTON DISTRIBUTION}

For Zooplankton, the Pseudocallanus elongatus ( a Copepod) was the highest in occurrence and abundance. It occurred in all the 7 stations studied and constituted by number $45.5 \%$ (or 307 out of the total population of 674) of the Zooplankton population. It was followed by Pondo leuceti and Evadne nordmani (both Cladocera). They constituted 9.3\% and $7.2 \%$ respectively or (63 and 49 ) in number and occurred in 5 out of the 7 stations studied. The Sagitella, Brachylum larva, Rhizosolane spp, Centropages typicus, Eucallanus elongatus and Macrocallanus elongatus all occurred in 1 station each out of the 7 studied making them the least in both abundance and distribution.

For the Phytoplankton, Cosnodiscus radiatus ( a Diatom) was the highest in abundance and occurrence. It occurred in all the 7 stations studied and constituted by number $48.4 \%$ (or 1052 out of the total population of 2172) of the Phytoplankton population. It was followed by Cosnodiscus lineatus and Biddulphia sinenses (all Diatom) in abundance constituting $9.5 \%$ and $9.02 \%$ respectively. But in distribution it was followed by Ceratium macrocerus ( Dinoflagellate) which occurred in all the stations but 7 and both Cosnodiscus granni and Biddulphia sinenses ( Both Diatom).both occurring in all stations but 4 and 1 .

\section{DISCUSSION}

The abundance and distribution of Plankton species in the Bonny Estuary is spectacular comprising a total of 63 species of both Phyto and Zooplankton. The qualitative and quantitative dominance of Diatom in the water is worthy of note. This is because, they have been known to be indicators of water quality and environmental conditions (Kelly, 1998; Weckstom et al, 1997 Mossa et al, 1996) .A rough combination of the 3 most abundant diatom Cosnodiscus radiatus, Cosnodiscus lineatus and Biddulphia sinenses will give $66.92 \%$. The dominant and wide occurrence of the Cosnodiscus Spp has also been observed in other work in the Gulf of Guinea (Olomukoro and Oronsaye 2009). Most of the Zooplankton Spp recorded here has been found in other works in Nigerian water and the Gulf of Guinea. Egborge (1987) recorded the occurrence of Evadne spp in Warri river while Olomukoro and Oronsaye (2009) recorded the occurrence of Crab zoea, Fish larvae „Evadne sp, Sagitta $s p$,Eucalanus sp, Polychaete larvae and Temora spp. In the Gulf of Guinea. Many Larva forms were found (8) in number, ranging from Fish to Arthropod larva to Crab Zoae. This is an indication that the place is a good breeding and nursery ground for most fishery resources. It is in agreement with the work of Odum (1971) who found out that natural tropical ecosystems are good breeding/ nursery ground for most of the aquatic fauna. It also agrees with Olomukoro and Oronsaye (2009) in their work in the Gulf of Guinea a known breeding ground for most fish fauna. Also, the fact that a copepod is the dominating Zooplankton support the claim that the Bonny estuary is a natural breeding ground for most aquatic fauna as Copepods have been known to constitute a major food source for most commercial fish spp.

According to Dugbeon et al (2006), the conservation and management of water ecosystem is critical to the interest of the entire mankind, as long as biodiversity constitutes valuable natural resources in economical, cultural aesthetic, scientific and educational terms. It is in view of this that the result from this work will serve as a background database for future reference in the management of this important water body.

\section{REFERENCES}

Abohweyere, P.O (1990). Study of Limnological parameters and potential fish yield in Kigera reservoir (Extensive system) in Kainji, New Bussa, Nigeria. Journal of Aquatic Sciences 5: 53 - 58

Adebisi A A (1981) The physicochemical hydrology of a tropical seasonal river - upper Ogun river. Hydrobiologia 179: 157 - 165

Dudgeon D, A H Arthington, M O Gesner, Z I Kawabata and D J Knowler (2006). HW Biodiversity: Importance, Threats, Status and Conservation challenges. Bio. Rev. $81: 163$ - 182.

Egborge A B M (1981) The composition, seasonal variation and distribution of Zooplankton in lake Asejire, Nigeria. Rev. Zoolo.afr,95,1 pp 136 - 163

Egborge, A.B.M. (1987). Salinity and distribution of cladocera in Warri River, Nigeria. Hydrobiologia. 145: $159-167$.

Fagade S O and Olaniyan C I O (1974) Seasonal distribution of the fish fauna in Lagos Lagoon. Bull. Inst. Fr. Afri. Noire Series A 36: 245 - 252 
Holden M J and Green J (1960). The hydrology and plankton of River Sokoto. Journal Animal Ecology 29: $65-84$

Kelly, M. G.( 1998). Use of the trophic diatom index to monitor eutrophication in rivers. Wat. Res. 32: $236-$ 242.

Margalef, R. (1951). Diversidad de especies en las comunidales naturales. Publ. Inst. Biol. Apl., 9: 5-27

Moser, K. A., Macdonald, G. M. and Smol, J. P. (1996). Applications of freshwater diatoms to geographical research. Progr. Phys.geigr 20: $21-52$.

Nwankwo D I (1986). Phytoplankton of a sewage disposal sight in Lagos Lagoon.l. The Algea. Nigerian Journal of Biological Sciences 1(2): 89 - 96

Nwankwo, D.I.( 2004). Studies on the Environmental preference of blue-green algae (cyanophyta) in Nigeria coastal waters. The Nigeria Environmental Society Journal, 2(1): 44 -51.

Odum, E. P. (1971). Fundamentals of ecology. 3rd edn. Saunderss Press, U.S.A. 574 pp.

Onyema I .C. (2007)The Phytoplankton Composition, Abundance and Temporal Variation of a Polluted Estuarine Creek in Lagos, Nigeria Turkish Journal of Fisheries and Aquatic Sciences 7: 89-96 (2007) Central Fisheries Research Institute (CFRI) Trabzon,
Turkey and Japan International Cooperation Agency (JICA)

Olaniyan, C.I.O. (1969). The seasonal variation in the hydrology and total plankton of the lagoons of South West-Nigeria. Nigerian Journal of Science, 3(2): 101119

Olomukoro J O and C. Oronsaye (2009). The Plankton Studies of the Gulf of Guinea, Nigeria. Biosc. Res. Comm. Vol 21 No 22009.

Shannon, C.E. and Weaver, W. (1949). The mathematical theory of communication Urban. Univ. Illinois Press. Illinois, $125 \mathrm{pp}$.

Ugwumba A A A (1990). food and feeding habit of Orochromis niluticus, sarotherodon melanotheron and Heterotis niloticus. ( Pieces Osteichthyes) in Awba Reservoir Ibadan. PhD Thesis, University of Ibadan, Ibadan.

Wackstrom, J.; Korhola, A. and Blom, T. (1997). Diatoms as quantitative indicators of $\mathrm{pH}$ and water temperature in subartic fennoscandian lakes. Hydrobiologia. 347: $171-184$

Williams V N (1962). The Seasonal distribution of the teleost fish fauna in lagos harbour, creek and Lagoon in relation to salt tolerance. M.Sc. Thesis, University of Wales. 